\title{
Effects of copper deficiency on hepatic and cardiac antioxidant enzyme activities in lactose- and sucrose-fed rats
}

\author{
BY S. M. LYNCH AND J. J.STRAIN* \\ Biomedical Sciences Research Centre, University of Ulster at Jordanstown, \\ Newtownabbey, Co. Antrim BT37 OQB, Northern Ireland
}

(Received 3 June 1988-Accepted 11 October 1988)

\begin{abstract}
1. A number of dietary sugars are known to mediate the effects of copper deficiency. The effects of lactose (compared with sucrose) and a dietary $\mathrm{Cu}$ deficiency on hepatic and cardiac antioxidant enzyme activities and tissue mineral element status were investigated in the rat.

2. Groups $(n 6)$ of male weanling Wistar rats were provided ad lib. with deionized water and diets containing sucrose $(580 \mathrm{~g} / \mathrm{kg})$ or sucrose and lactose $(387 \mathrm{~g} / \mathrm{kg}$ and $193 \mathrm{~g} / \mathrm{kg}$ respectively) with either control $(12.0 \mathrm{mg} / \mathrm{kg})$ or deficient $(1.5 \mathrm{mg} / \mathrm{kg})$ quantities of $\mathrm{Cu}$ for $77 \mathrm{~d}$.

3. Animals consuming the low-Cu diets exhibited significantly decreased tissue $\mathrm{Cu}$ levels $(P<0 \cdot 01)$, hepatic and cardiac cytochrome $c$ oxidase $(E C 1.9 .3 .1, C C O)$ activities $(P<0.01$ and $P<0.001$ respectively) and hepatic $\mathrm{Cu}$-zinc superoxide dismutase (EC 1.15.1.1, CuZnSOD) activity $(P<0.05)$. The low-Cu diets also significantly decreased cardiac manganese superoxide dismutase (EC 1.15.1.1, MnSOD), catalase (EC 1.11.1.6) and glutathione peroxidase (EC 1.11.1.9, GSH-Px) activities $(P<0.01, P<0.05$ and $P<0.001$ respectively).

4. Hepatic $\mathrm{Mn}$ was significantly increased in both lactose-fed $(P<0.001)$ and $\mathrm{Cu}$-deficient $(P<0.01)$ animals. These increases were unrelated to hepatic MnSOD activity. Cardiac $\mathrm{Zn}$ was significantly $(P<0 \cdot 01)$ increased in Cu-deficient animals.

5. Lactose feeding resulted in significantly increased cardiac CCO activity $(P<0.001)$ but significantly decreased hepatic CuZnSOD $(P<0.05)$, catalase $(P<0.01)$ and GSH-Px $(P<0.001)$ activities.

6. The activities of lactose dehydrogenase $(E C$ 1.1.1.27, LDH) and glucose-6-phosphate dehydrogenase (EC 1.1.1.49, G6PDH) were found to be significantly $(P<0.05$ and $P<0.01$ respectively) increased in $\mathrm{Cu}$-deficient animals and G6PDH activity was significantly $(P<0.01)$ decreased as a result of lactose consumption.

7. The observed changes in antioxidant enzyme activities associated with both $\mathrm{Cu}$ deficieny and lactose consumption may have important implications for the development of free radical mediated cell damage. However, no significant differences in either hepatic or cardiac levels of thiobarbituric acid reactive substances, a measure of lipid peroxidation, were found.
\end{abstract}

The involvement of copper in lipid and glucose metabolism and cardiac function in man has prompted Klevay (1983) to propose that a dietary $\mathrm{Cu}$ deficiency may be of major importance in the aetiology of ischaemic heart disease (IHD). $\mathrm{Cu}$ is also an essential component of several enzymes including the $\mathrm{Cu}$-zinc form of the antioxidant enzyme superoxide dismutase (EC 1.15.1.1; CuZnSOD) (Fridovich, 1975). This enzyme and the other cellular antioxidant enzymes, catalase $(E C$ 1.11.1.6), the selenoenzyme glutathione peroxidase (EC 1.11.1.9; GSH-Px) and manganese superoxide dismutase (EC 1.15.1.1; MnSOD), perform an important function in protecting the cell from the potentially harmful effects of oxygen free-radicals (Blake et al. 1987). A link between IHD and chronic inflammation has been recognized (Majno et al. 1985), and since $\mathrm{O}_{2}$ free-radicals are important in the development of inflammation and peroxidative damage (Blake et al. 1987), these cellular antioxidant enzymes may play an important protective role against the development of IHD.

The consumption of milk has been identified in several epidemiological studies as correlating with the incidence of IHD (see Strain, 1988). The high fat content of milk was initially proposed (Briggs et al. 1960) as a putative causal factor, but more recently attention has focused on both the protein (Beynen et al. 1983; Stemmer et al. 1985) and carbohydrate (Segall, 1980; Pearce, 1984; Lember \& Tamm, 1988) fractions.

\footnotetext{
* For reprints
} 
Table 1. Composition $(\mathrm{g} / \mathrm{kg})$ of diets

\begin{tabular}{|c|c|c|c|c|}
\hline \multirow[b]{3}{*}{ Component } & \multicolumn{4}{|c|}{ Diets } \\
\hline & \multicolumn{2}{|c|}{ Sucrose } & \multicolumn{2}{|c|}{ Lactose } \\
\hline & Control & Cu-deficient & Control & $\mathrm{Cu}$-deficient \\
\hline Sucrose* & 580 & 580 & 387 & 387 \\
\hline Lactose $\dagger$ & - & - & 193 & 193 \\
\hline Fibrous cellulose powder $\dagger$ & 30 & 30 & 30 & 30 \\
\hline Casein $\dagger$ & 200 & 200 & 200 & 200 \\
\hline Maize oil $\ddagger$ & 100 & 100 & 100 & 100 \\
\hline Rat vitamin mix§ & 10 & 10 & 10 & 10 \\
\hline Vitamin A, D, E, K mix $\|$ & 30 & 30 & 30 & 30 \\
\hline Mineral mix & 50 & 50 & 50 & 50 \\
\hline $\mathrm{CuSo}_{4} \cdot 5 \mathrm{H}_{2} \mathrm{O}$ & 0.06 & - & 0.06 & - \\
\hline
\end{tabular}

* William McKinney Ltd, Belfast.

$\dagger$ Sigma Chemical Co., Poole, Dorset.

\$ Mazola Corn Oil, Corn Products Co.

$\S$ Contained in sucrose ( $\mathrm{mg} / \mathrm{kg}$ diet): choline chloride 1000 , thiamin 16 , riboflavin 16 , pyridoxal hydrochloride 16 , calcium pantothenate 40 , biotin 0.52 , cyanocobalamin 0.06 , pteroylmonoglutamic acid $5 \cdot 25$, nicotinamide 15 .

$\|$ Contained in maize oil ( $\mathrm{mg} / \mathrm{kg}$ diet): retinol acetate 36 , cholecalciferol $0 \cdot 07, \alpha$-tocopheryl acetate 20 , menadione 10.

I Contained (g/kg diet): $\mathrm{CaCO}_{3} 10.56, \mathrm{CaHPO}_{4} .2 \mathrm{H}_{2} \mathrm{O} 16.45, \mathrm{ZnSO}_{4} 0 \cdot 21, \mathrm{MgCO}_{3} 0.98, \mathrm{MgSO}_{4} .7 \mathrm{H}_{2} \mathrm{O} 1 \cdot 18$, $\mathrm{NaCl} 5.02, \mathrm{KCl} \mathrm{0.83,} \mathrm{FePO}_{4} 1.58, \mathrm{KH}_{2} \mathrm{PO}_{4} 12 \cdot 46, \mathrm{MnSO}_{4} \cdot \mathrm{H}_{2} \mathrm{O} 0.75, \mathrm{AlK}\left(\mathrm{SO}_{4}\right)_{2} \cdot 12 \mathrm{H}_{2} \mathrm{O} 0.0095, \mathrm{KIO}_{3} 0.03$, $\mathrm{CoCl}_{2} \cdot 6 \mathrm{H}_{2} \mathrm{O} 0.0024$, NaF 0.04, $\mathrm{Na}_{2} \mathrm{MoO}_{4} \cdot 4 \mathrm{H}_{2} \mathrm{O} 0.0057$, Tris-CrCl $(157 \mathrm{~g} / \mathrm{kg}) 0.8 \mathrm{mg}, \mathrm{Na}_{2} \mathrm{SeO}_{3} .5 \mathrm{H}_{2} \mathrm{O} 0.5 \mathrm{mg}$.

Common dietary sugars, e.g. sucrose and fructose, have been shown to affect $\mathrm{Cu}$ status adversely in experimental animals and human beings (e.g., Holbrook et al. 1986; Johnson $\&$ Hove, 1986), and milk-based diets have been widely used to induce $\mathrm{Cu}$ deficiency in experimental animals (e.g. Kincaid \& Carlton, 1982; Stemmer et al. 1985). Although lactose is one of the main dietary sugars in those countries experiencing a high incidence of IHD (Gray, 1971), few studies have examined the potential effects of this sugar on $\mathrm{Cu}$ status. The aim of the present study was to investigate possible effects of lactose consumption on cellular antioxidant and related enzyme activities and on $\mathrm{Cu}$ and selected trace element status in animals receiving control and $\mathrm{Cu}$-deficient diets.

\section{EXPERIMENTA L}

\section{Animals, diets and tissue preparation}

Groups ( $n$ 6) of male, weanling, Wistar rats with mean initial body-weights matched to within $0.5 \mathrm{~g}$ (mean initial weight $(n 24), 60.8$ (SE 2.8) $\mathrm{g}$ ) were used. The animals were housed individually in stainless-steel and polypropylene cages and maintained at $25^{\circ}$ with a $12 \mathrm{~h}$ light-12 h dark cycle. Diets (Table 1), containing sucrose or sucrose and lactose with either control $(12.0 \mathrm{mg} / \mathrm{kg})$ or deficient $(1.5 \mathrm{mg} / \mathrm{kg})$ quantities of $\mathrm{Cu}$, were provided ad lib. with deionized water for $77 \mathrm{~d}$.

After this period the animals were anaesthetized with diethyl ether and killed by exsanguination. The liver and heart were removed immediately and placed in ice-cold $0.25 \mathrm{M}$-sucrose, $\mathrm{pH} 7 \cdot 4$. After weighing these organs a representative portion of the liver and the entire heart were stored at $-20^{\circ}$. The remainder of the liver (approximately $9 \mathrm{~g}$ ) was finely minced and homogenized in $0.25 \mathrm{M}$-sucrose buffer, $\mathrm{pH} 7.4(20 \mathrm{ml})$. The homogenate was centrifuged $(800 \mathrm{~g}, 5 \mathrm{~min})$ after which the supernatant fraction was 
removed and the pellet resuspended in fresh sucrose buffer $(20 \mathrm{ml})$. The resuspended pellet was centrifuged $(800 \mathrm{~g}, 5 \mathrm{~min})$, the supernatant fraction pooled with that from the initial centrifugation and this solution was diluted to $90 \mathrm{ml}$ with sucrose buffer. This supernatant solution was stored at $-20^{\circ}$ in $3-4 \mathrm{ml}$ portions. Heart homogenates $(100 \mathrm{mg} / \mathrm{ml})$ were prepared as described previously from the frozen hearts but without the centrifugation steps. Appropriate dilutions of the heart and liver homogenates were used for the various enzyme assays.

\section{Analytical methods}

Superoxide dismutase was assayed by the method of Oberley \& Spitz (1984), using the modification suggested by Flohe \& Otting (1984) in order to minimize interferences. Catalase was assayed by the method of Aebi (1974), and GSH-Px by that of Paglia \& Valentine (1967) using $1.5 \mathrm{~mm}$-hydrogen peroxide as substrate in an assay mixture containing $1.0 \mathrm{mM}$-sodium azide to inhibit catalase. Cytochrome $c$ oxidase $(E C$ 1.9.3.1; $\mathrm{CCO})$, glucose-6-phosphate dehydrogenase (EC1.1.1.49; G6PDH) and lactate dehydrogenase $(E C$ 1.1.1.27; $\mathrm{LDH})$ activities were measured by the methods of Cooperstein \& Lazarow (1951), Kornberg et al. (1955) and Wroblewski \& LaDue (1955) respectively. Protein was estimated by the method of Bradford (1976) using bovine serum albumin as a standard.

Samples of liver and heart which had been stored at $-20^{\circ}$ were thawed and dried to constant weight in an oven at $80^{\circ}$. The dried liver and heart samples were digested in nitric acid at $80^{\circ}$ until a clear solution was obtained. After dilution with deionized water, atomic absorption spectrophotometry (AAS) was performed to determine mineral levels using suitable control samples.

Hepatic and cardiac peroxidative damage was estimated by measuring the levels of thiobarbituric acid reactive substances (TBARS) present in uncentrifuged tissue homogenates $(100 \mathrm{mg} / \mathrm{ml})$ prepared from samples which had been stored at $-20^{\circ}$, using the method of Ohkawa et al. (1979) with 1,1,3,3-tetramethoxypropane (TMP) as an external standard.

\section{Statistical analysis}

Results were analysed for significance by two-way analysis of variance (ANOVA) in order to investigate the independent effects of $\mathrm{Cu}$ deficiency and lactose consumption and to establish the influence on cellular processes of interactions between these dietary factors. Results are given as means with their standard errors.

RESULT'S

Lactose consumption resulted in significant $(P<0.05)$ growth retardation (final bodyweights: sucrose-fed animals $391 \cdot 1$ (SE 7.4) g, lactose-fed animals 347.8 (SE 14.4) g), while Cu deficiency had no significant effect on growth. Neither relative liver nor heart sizes $(\mathrm{g} / \mathrm{kg}$ body-weight) were significantly influenced by dietary lactose or $\mathrm{Cu}$ deficiency.

Two-way ANOVA of the results obtained for the hepatic and cardiac indices of $\mathrm{Cu}$ status (Table 2) showed that animals consuming the $\mathrm{Cu}$-deficient diet, when compared with those on control diet, had significantly decreased hepatic and cardiac $\mathrm{Cu}(P<0.01)$ and hepatic and cardiac $\mathrm{CCO}$ activities $(P<0.01$ and $P<0.001$ respectively). These animals also exhibited significantly decreased hepatic CuZnSOD activity $(P<0.05)$. Cardiac $\mathrm{Cu}$ and CCO activity were both significantly $(P<0.05$ and $P<0.001)$ higher in the lactose-fed animals compared with those fed only sucrose, while hepatic CuZnSOD activity was significantly $(P<0.05)$ lowered. Significant carbohydrate and $\mathrm{Cu}$ interactions were observed for hepatic CuZnSOD $(P<0.01)$ and cardiac CCO $(P<0.05)$ activities. Compared with controls the activity of the former enzyme increased with consumption of 


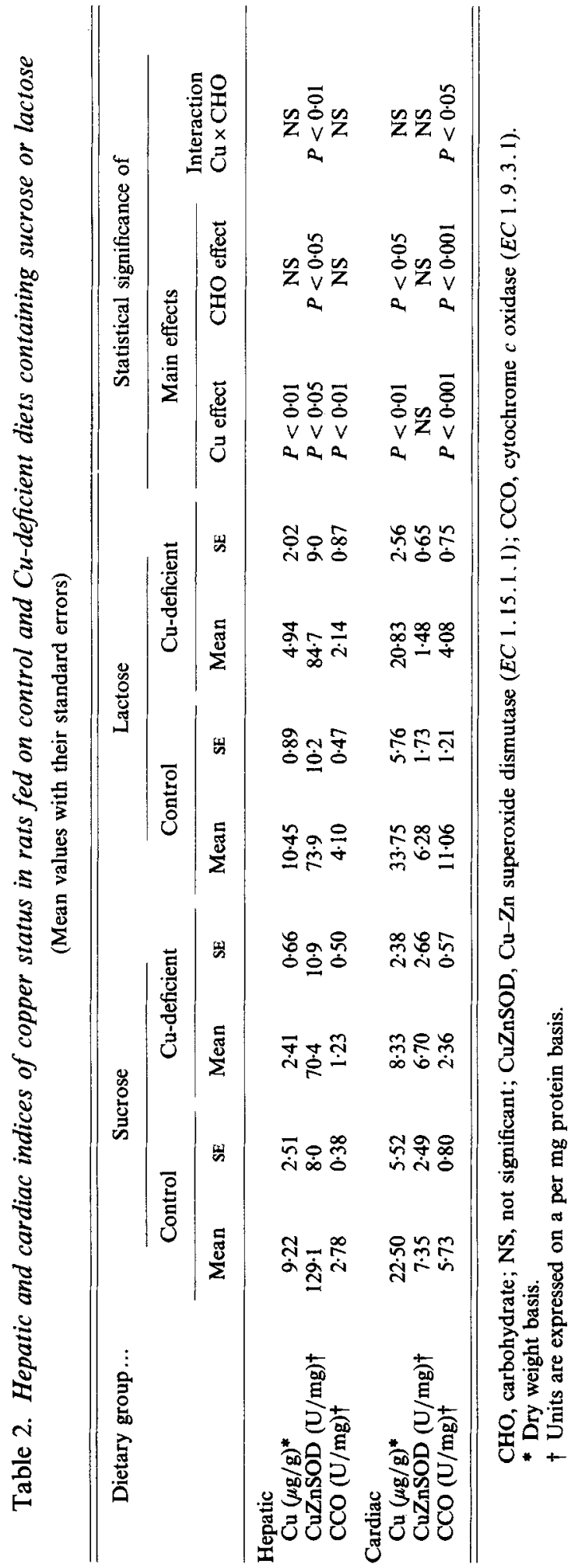


Lactose, copper and antioxidant enzymes

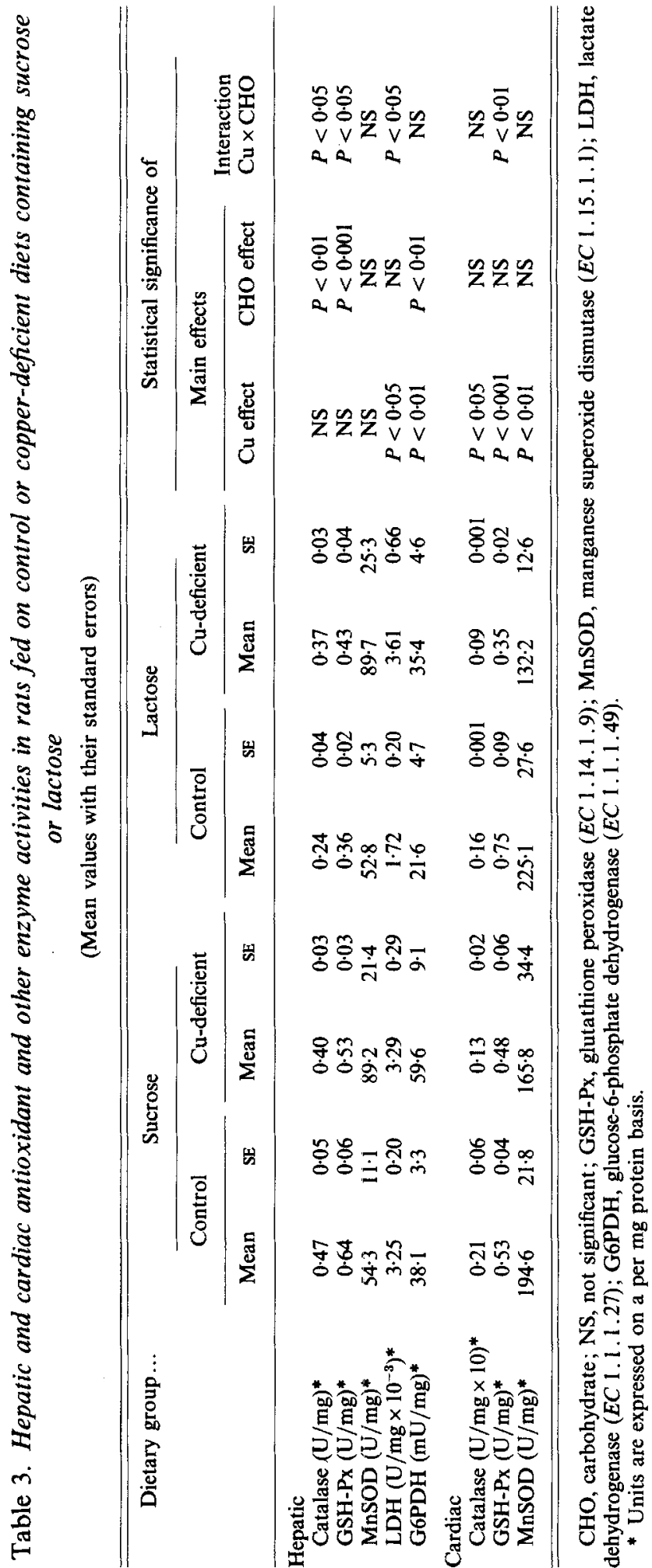


S. M. LYNCH AND J. J. STRAIN

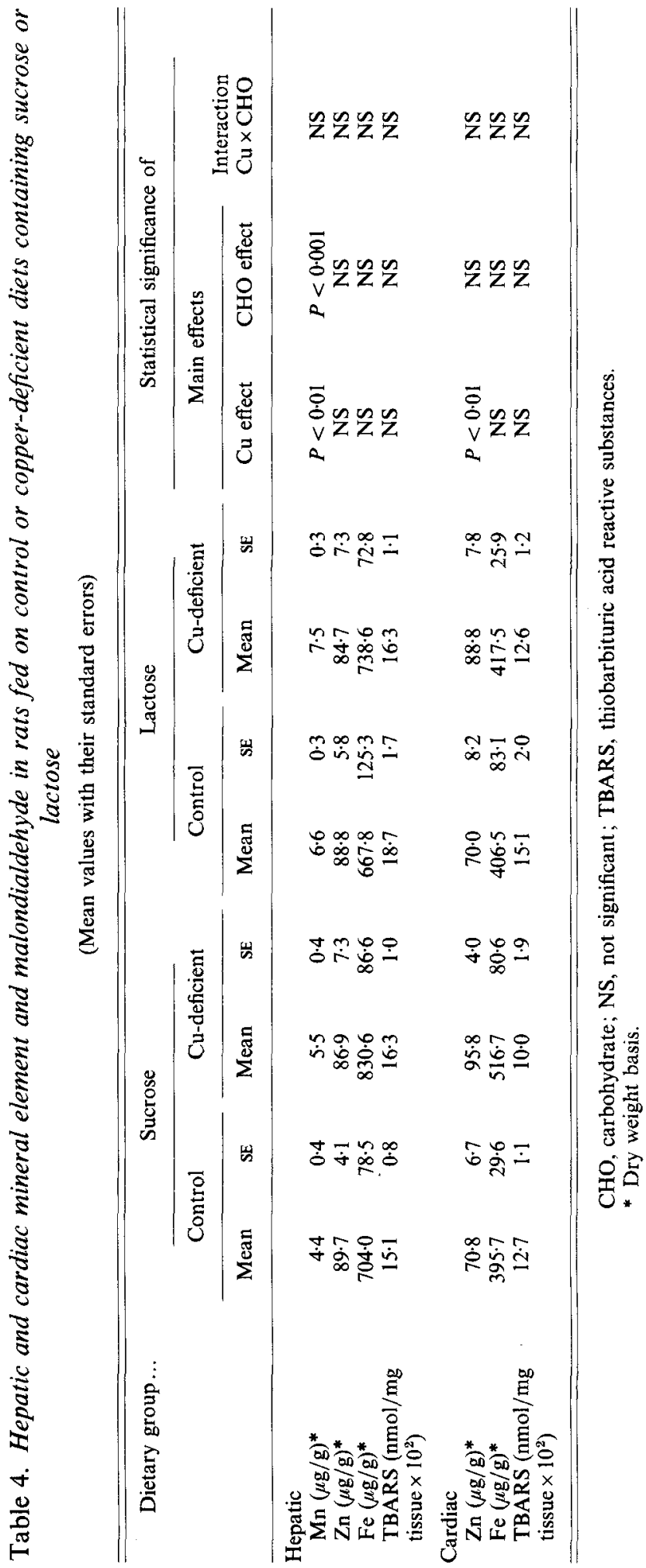


the Cu-deficient lactose diet, in contrast to the marked decrease in activity with the $\mathrm{Cu}$ deficient sucrose diet.

The hepatic and cardiac activities of the antioxidant enzymes MnSOD, GSH-Px and catalase are reported in Table 3 . Lactose consumption resulted in significantly $(P<0.01$ and $P<0.001$ respectively) decreased hepatic catalase and GSH-Px activities. Except CuZnSOD, none of the hepatic antioxidant enzyme activities was significantly influenced by $\mathrm{Cu}$ deficiency. $\mathrm{Cu}$ deficiency, however, resulted in significantly decreased cardiac catalase, GSH-Px and MnSOD $(P<0.05, P<0.001$ and $P<0.01$ respectively) activities. There were also significant carbohydrate and $\mathrm{Cu}$ interactions for hepatic and cardiac GSHPx $(P<0.05$ and $P<0.01$ respectively $)$ and hepatic catalase $(P<0.05)$ activities.

Cu deficiency significantly $(P<0.01)$ increased, while lactose consumption significantly $(P<0.01)$ decreased, hepatic G6PDH activity (Table 3$)$. Hepatic LDH activity was significantly $(P<0.05)$ decreased with lactose, compared with sucrose, consumption and a significant $(P<0.05)$ carbohydrate and $\mathrm{Cu}$ interaction was also noted.

The hepatic and cardiac levels of $\mathrm{Cu}$ are reported in Table 2. AAS determinations of the hepatic and cardiac levels of $\mathrm{Mn}, \mathrm{Zn}$ and iron levels are reported in Table 4. Hepatic $\mathrm{Mn}$ was found to be significantly increased in both $\mathrm{Cu}$-deficient $(P<0.01)$ and lactose-fed animals $(P<0.001)$. Cardiac Mn was below the detection limit (i.e. $<1.0 \mu \mathrm{g} / \mathrm{g}$ dry weight) of the instrumentation available. Cardiac $\mathrm{Zn}$ was found to be significantly $(P<0.01)$ increased as a result of $\mathrm{Cu}$ deficiency, and there were no significant alterations of $\mathrm{Fe}$ in any of the experimental groups. No significant differences in hepatic or cardiac TBARS levels (Table 4) were found as a result of either $\mathrm{Cu}$ deficiency or dietary carbohydrate.

\section{DISCUSSION}

The results indicate that the low-Cu diets induced a mild $\mathrm{Cu}$ deficiency in the experimental animals. Tissue $\mathrm{Cu}$ and $\mathrm{CCO}$ activity were found to be significantly decreased as a result of the low-Cu diets in both the liver and heart, while $\mathrm{CuZnSOD}$ activity was significantly decreased only in hepatic tissue. However, the low-Cu diets did not significantly affect growth rate or relative heart size.

The significantly lower cardiac $\mathrm{Cu}$ and $\mathrm{CCO}$ activity in those animals fed on sucrose-, compared with lactose-containing diets, suggests that sucrose, compared with lactose, may exacerbate the effects of a dietary $\mathrm{Cu}$ deficiency. The observations in the present study would lend support to the results of Petering et al. (1986), who found that the physiological and biochemical effects of $\mathrm{Cu}$ deficiency are significantly exacerbated with sucrose compared with a starch-lactose $(1: 1, \mathrm{w} / \mathrm{w})$ diet, and it has been suggested that the protein in milk powder is the causative factor resulting in the increased morbidity and mortality associated with milk-based $\mathrm{Cu}$-deficient diets compared with those based on other protein sources (Stemmer et al. 1985). In the current study, although some indices of Cu status were higher in rats fed on lactose, others were unaffected and hepatic CuZnSOD activity was significantly lowered. However, there is some evidence that CuZnSOD may be induced by free radical production (Jannson et al. 1985) and CCO activity has been used by many investigators (e.g. Trayhurn \& Jennings, 1987) as a measure of tissue mitochondrial content. Thus, it would appear that neither measurement is influenced by $\mathrm{Cu}$ status alone.

Increased hepatic and cardiac $\mathrm{CCO}$ activities (Table 2) suggest that lactose feeding may result in increased mitochondrial respiration in these tissues, with a possible concomitant rise in $\mathrm{O}_{2}$ demand. Since it has been shown that $\mathrm{O}_{2}$ consumption increases dramatically in arterial and cardiac tissue during experimentally induced atherosclerosis (e.g. Morrison et al. 1972; Stange \& Papenberg, 1978; Thuesen et al. 1984), any increase in mitochondrial 
respiration could have important implications for the development of coronary atherosclerotic lesions and cardiac dysfunction. Increased tissue $\mathrm{O}_{2}$ consumption may increase $\mathrm{O}_{2}$ free-radical production and thus lead to the generation of potentially harmful lipid hydroperoxides (Blake et al. 1987). However, when the hepatic and cardiac TBARS levels (a measure of lipid peroxidation) were determined, no significant differences among any of the dietary groups were observed. Diets deficient in $\mathrm{Cu}$ have previously been shown to result in increased lipid peroxidation (Paynter, 1980) and the absence of lipid peroxidation in the present study may be due either to the decreased severity of the $\mathrm{Cu}$ deficiency experienced by the rats, or the recognized limitations of the thiobarbituric acid assay in estimating lipid peroxidation (Slater, 1984).

Lactose feeding resulted in significantly decreased G6PDH activity, while $\mathrm{Cu}$ deficiency caused significantly increased G6PDH activity (Table 3). Although similar changes in G6PDH activity associated with both $\mathrm{Cu}$ deficiency (Lynch \& Strain, 1988) and lactose feeding (Michaelis \& Szepesi, 1973) have been observed previously, their importance is, as yet, unclear.

In agreement with a number of other studies using milk-based diets (e.g. Gruden, 1976; King et al. 1979), the present results showed that dietary lactose significantly increased hepatic Mn (Table 4). However, at least one study has shown the opposite (King et al. 1980), and so the exact nature of the interaction between dietary lactose and tissue $\mathrm{Mn}$ status is currently uncertain. In the present study hepatic Mn significantly increased with $\mathrm{Cu}$ deficiency (Table 4), while the activity of cardiac MnSOD significantly decreased with $\mathrm{Cu}$ deficiency (Table 3). The latter result is in agreement with Paynter (1980), who found that the lowered activity of tissue CuZnSOD was not compensated for by any increase in MnSOD activity in the rat, rather a decrease in MnSOD activity was observed. Murthy et al. (1974) found inverse relations between $\mathrm{Zn}$ and $\mathrm{Cu}$ levels only in some tissues in the rat. In the current study cardiac, but not hepatic, $\mathrm{Zn}$ was significantly increased by $\mathrm{Cu}$ deficiency. $\mathrm{Cu}$ deficiency has also been shown in several studies (see Fields et al. 1984) to decrease cellular activities of the selenoenzyme GSH-Px and a similar effect of Cu deficiency on the major biochemically active form of Se was observed in cardiac tissue (Table 3).

Observations in the current study support the work of others with respect to interactions between $\mathrm{Cu}$ deficiency and the apparent body status of $\mathrm{Mn}$, Se and $\mathrm{Zn}$. Lactose, compared with sucrose, consumption decreased the activities of cytosolic antioxidant enzymes, including the $\mathrm{Cu}$-dependent enzyme $\mathrm{CuZnSOD}$. Lactose consumption, however, appeared to increase other indices of $\mathrm{Cu}$ status, including the mitochondrial marker enzyme $\mathrm{CCO}$. These results suggest that components in milk other than lactose may interact with $\mathrm{Cu}$ deficiency to produce the increased morbidity and mortality associated with milk-based diets.

S.M.L. acknowledges receipt of a Northern Ireland Chest, Heart \& Stroke Association research studentship. The authors wish to thank Mr K. McAdam for his assistance in the maintenance of the experimental animals.

\section{REFERENCES}

Aebi, H. (1974). Catalase. In Methods of Enzymatic Analysis, pp. 673-684 [H. U. Bergmeyer, editor]. New York: Academic Press.

Beynen, A. C., den Engelsman, G., Scholz, K. E. \& West, C. E. (1983). Casein-induced hypercholesterolaemia in rabbits : distribution of cholesterol, triglycerides and phospholipids between serum and liver. Annals of Nutrition and Metabolism 27, 117-124.

Blake, D. R., Allen, R. E. \& Lunec, J. (1987). Free radicals in biological systems - a review orientated to inflammatory processes. British Medical Bulletin 43, 371-385.

Bradford, M. M. (1976). Rapid and sensitive method for quantitation of microgram quantities of protein utilizing the principle of protein-dye binding. Analytical Biochemistry 72, 248-254. 
Briggs, R. D., Rosenberg, M. L., O’Neal, R. M., Thomas, W. A. \& Hartroft, W. S. (1960). Myocardial infarction in patients treated with Sippy and other high-milk diets. Circulation 21, 538-542.

Cooperstein, S. J. \& Lazarow, A. (1951). A microspectrophotometric method for the determination of cytochrome oxidase. Journal of Biological Chemistry 189, 665-670.

Fields, M., Ferretti, R. J., Reiser, S. \& Smith, J. C. Jr, (1984). The severity of copper deficiency in rats is determined by the type of dietary carbohydrate. Proceedings of the Society for Experimental Biology and Medicine 175, 530-537.

Flohe, L. \& Otting, F. (1984). Superoxide dismutase assays. Methods in Enzymology 105, 93-104.

Fridovich, I. (1975). Superoxide dismutases. Annual Review of Biochemistry 44, 147-159.

Gray, G. M. (1971). Intestinal digestion and maldigestion of dietary carbohydrates. Annual Review of Medicine 22, 391-404.

Gruden, N. (1976). The effect of milk diet on manganese transport through the rat's duodenal wall. Nutrition Reports International 14, 515-520.

Holbrook, J., Fields, M., Smith, J. C. Jr, Reiser, S. \& Los Alamos Medical Research Group (1986). Tissue distribution and excretion of copper-67 intraperitoneally administered to rats fed fructose or starch. Journal of Nutrition 116, 831-838.

Jannson, L. T., Perkkio, M. V., Willis, W. T., Refino, C. J., \& Dallman, P. R. (1985). Red cell superoxide dismutase is increased in iron deficiency anemia. Acta Haematologica 74, 218-221.

Johnson, M. A. \& Hove, S. S. (1986). Development of anemia in copper-deficient rats fed high levels of dietary iron and sucrose. Journal of Nutrition 116, $1225-1238$.

Kincaid, S. A. \& Carlton, W. W. (1982). Experimental copper deficiency in laboratory mice. Laboratory Animal Science 32, 491-494.

King, B. D., Lassiter, J. W., Neathery, M. W., Miller, W. J. \& Gentry, R. P. (1979). Manganese retention in rats fed different diets and chemical forms of manganese. Journal of Animal Science 49, 1235-1241.

King, B. D., Lassiter, J. W., Neathery, M. W., Miller, W. J. \& Gentry, R. P. (1980). Effect of lactose, copper and iron on manganese retention and tissue distribution in rats fed dextrose and casein diets. Journal of Animal Science 50, 452-458.

Klevay, L. M. (1983). Copper and ischemic heart disease. Biological Trace Element Research 5, 245-255.

Kornberg, A., Horecker, B. L. \& Smyriot, P. Z. (1955). Glucose-6-phosphate dehydrogenase - 6-Phosphogluconic dehydrogenase. Methods in Enzymology 1, 323-327.

Lember, M. \& Tamm, A. (1988). Lactose absorption and milk-drinking habits in Estonians with myocardial infarction. British Medical Journal 296, 95-96.

Lynch, S. M. \& Strain, J. J. (1988). Effects of dietary copper deficiency on hepatic antioxidant enzymes in male and female rats. Nutrition Reports International 37, 1127-1134.

Majno, G., Jorris, I. \& Zand, T. (1985). Atherosclerosis: new horizons. Human Pathology 16, 3-5.

Michaelis, O. E. IV \& Szepesi, B. (1973). Effect of various sugars on hepatic glucose-6-phosphate dehydrogenase, malic enzyme and total liver lipid of the rat. Journal of Nutrition 103, 697-705.

Morrison, E. S., Scott, R. F., Kroms, M. \& Frick, J. (1972). Glucose degradation in normal and atherosclerosic aortic intima-media. Atherosclerosis 16, 175-184.

Murthy, L., Klevay, L. M. \& Petering, H. G. (1974). Interrelationships of zinc and copper nutriture in the rat. Journal of Nutrition 104, 1458-1465.

Oberley, L. W. \& Spitz, D. R. (1984). Assay of superoxide dismutase activity in tumor tissue. Methods in Enzymology 105, 457-464.

Ohkawa, H., Ohishi, N. \& Yagi, K. (1979). Assay for lipid peroxides in animal tissues by thiobarbituric acid reaction. Analytical Biochemistry 95, 351-358.

Paglia, D. E. \& Valentine, W. N. (1967). Studies on quantitative and qualitative characterization of erythrocyte glutathione peroxidase. Journal of Laboratory and Clinical Medicine 70, 158-160.

Paynter, D. I. (1980). The role of dietary copper, manganese, selenium, and vitamine $\mathrm{E}$ in lipid peroxidation in tissues of the rat. Biological Trace Element Research 2, 121-135.

Pearce, R. J. (1984). Correlation of coronary heart disease with milk consumption: is protein or some other factor involved? Medical Hypotheses 14, 259-260.

Petering, H. G., Murthy, L., Stemmer, K. L., Finelli, V. N. \& Menden, E. E. (1986). Effects of copper deficiency on the cardiovascular system of the rat. Biological Trace Element Research 9, 251-270.

Segall, J. J. (1980). Hypothesis. Is milk a dietary risk factor for ischaemic heart disease? International Journal of Epidemiology 9, 271-276.

Slater, T. F. (1984). Overview of methods used for detecting lipid peroxidation. Methods in Enzymology 105, 283-293.

Stange, E. \& Papenberg, J. (1978). Changes in chemical and metabolic properties of rabbit aorta by dietary cholesterol and saturated and poly-unsaturated fats. Atherosclerosis 29, 467-476.

Stemmer, K. L., Petering, H. G., Murthy, L., Finelli, V. N. \& Menden, E. E. (1985). Copper deficiency effects on cardiovascular system and lipid metabolism in the rat; the role of dietary proteins and excessive zinc. Annals of Nutrition and Metabolism 29, 332-347.

Strain, J. J. (1988). Milk consumption, lactose and copper in the aetiology of ischaemic heart disease. Medical Hypotheses 25, 99-101. 
Thuesen, L., Nielsen, T. T., Thomassen, A. \& Bagger, J. P. (1984). Beneficial effect of a low-fat low-calorie diet on myocardial energy metabolism in patients with angina pectoris. Lancet ii, 59-62.

Trayhurn, P. \& Jennings, G. (1987). Functional atrophy of brown adipose tissue during lactation in mice. Biochemical Journal 248, 273-276.

Wroblewski, F. \& LaDue, J. S. (1955). Lactic dehydrogenase activity in blood. Proceedings of the Society for Experimental Biology and Medicine 90, 210-213. 